\title{
PETROLOGY AND STRUCTURE OF THE EARLY PROTEROZOIC PIRILÄ GOLD DEPOSIT IN SOUTHEASTERN FINLAND
}

\author{
HANNU MAKKONEN and ELIAS EKDAHL
}

\begin{abstract}
MAKKONEN, HANNU and EKDAHL, ELIAS, 1988. Petrology and structure of the early Proterozoic Pirilä gold deposit in southeastern Finland. Bull. Geol. Soc. Finland 60, Part 1, 55-66.

The Pirilä gold deposit is located in the southeastern part of the Ladoga-Botnian Bay Zone, in a volcano-sedimentary environment metamorphosed under PT conditions of the amphibolite facies. Metavolcanic rocks include felsic and intermediate pyroclastics and tholeiitic to komatiitic lavas. The stratigraphically underlying metasedimentary rocks are mainly graywackes with some limestone and calc-silicate rocks.

Sulfide and gold bearing quartz veins and lenses occur in a transitional zone between volcanic and sedimentary units, the latter including a narrow iron formation of silicate, oxide, and sulfide facies. The quartz veins and lenses were emplaced during the $\mathrm{F}_{2}$ and $\mathrm{F}_{3}$ deformational phases.

The most common ore minerals are arsenopyrite, löllingite, pyrrhotite, and pyrite. In some places there is also abundant galena, sphalerite, and chalcopyrite. Gold and sulfides are associated with either quartz lenses and veins or with quartzcummingtonite rock. The gold occurs predominantly as inclusions in arsenopyrite or in löllingite, and is only rarely visible macroscopically. The grains are mostly electrum, the silver content of the analyzed grains ranging between 10.6 and 60.0 percent. Silver also occurs as small dyscrasite inclusions in galena.

The in situ ore reserves of the Pirilä deposit are $150,000 \mathrm{t}$ at $8 \mathrm{~g} / \mathrm{t}$ gold and 30 $\mathrm{g} / \mathrm{t}$ silver. Smaller gold occurrences in a similar stratigraphic position are found near the Pirilä deposit. Further indications of gold are met along the same stratigraphic horizon over a distance of at least 30 kilometers.
\end{abstract}

Key words: gold ores, metavolcanic rocks, metasedimentary rocks, structural geology, ore minerals, chemical composition, Proterozoic, Pirilä, Rantasalmi, Finland.

Hannu Makkonen and Elias Ekdahl: Geological Survey of Finland, Exploration Department, P.O. Box 237, 70101 Kuopio, Finland.

\section{Introduction}

The Pirilä gold deposit is located in southeastern Finland in the municipality of Rantasalmi, about $100 \mathrm{~km}$ south of the city of Kuopio.

In the early 1970 s the Geological Survey of Finland undertook exploration in the Pirilä area and south of it. As a result many boulders with eco- nomically significant $\mathrm{Cu}, \mathrm{Zn}$, or $\mathrm{Pb}$ contents and some with notable gold and silver contents were discovered. However, the sources of the boulders were not found. In spring 1983 the Geological Survey of Finland reopened investigations in the area, with the above boulders as the starting point. The Pirilä gold deposit was discovered in an outcrop in summer 1983.

The diamond core drilling conducted 1983-84 
establishes in situ ore reserves of $150,000 \mathrm{t}$ at 8 $\mathrm{g} / \mathrm{t}$ gold and $30 \mathrm{~g} / \mathrm{t}$ silver.

This paper describes the deposit, its structure and mineralogy, and the geology of the Pirilä area. The origin of the ore is also discussed.

\section{Geology of the Pirilä area}

The Pirilä area lies in a transitional zone between the Proterozoic Svecofennian and Karelian schist belts, which represent different types of sedimentary association of the same Svecokarelian orogenic cycle (Simonen 1980). The transitional zone partly overlaps the Main Sulphide Ore Belt (Kahma 1973).

The bedrock of the Pirilä area consists mainly of dome-like tonalite bodies surrounded by supracrustal rocks including mica schists, felsic to mafic volcanics, komatiites, and narrow layers of limestone and iron formation. Small granite intrusions also occur.

In the northern part of the area, the mica schists exhibit well-preserved sedimentary structures such as graded bedding, cross bedding, lamination, and slump structures, which led to their being interpreted as turbidites by Gaál and Rauhamäki (1971). Black shale intercalations also occur in this part of the area.

Of pyroclastic origin, the felsic volcanic rocks now occur as rather homogeneous quartz-

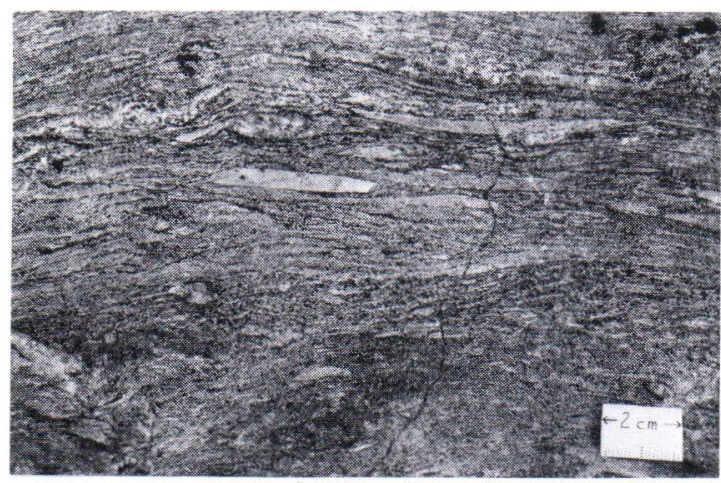

Fig. 1. Felsic lapilli tuff near the contact with mica schist. feldspar gneisses. However, in places, particularly in the lower part of the sequence, lapilli and agglomerate structures are evident (Fig. 1). The intermediate volcanics, too, are of pyroclastic origin, and the porphyritic texture is still visible despite strong foliation. Plagioclase and hornblende occur as phenocrysts, and hornblende is an alteration product of clinopyroxene, remnants of which are still encountered. Felsic lapilli and bombs also occur in the intermediate volcanics.

Amphibolitic mafic volcanics consist predominantly of pillow lavas. The central gas cavities and amygdules in the pillows and, sometimes also the matrix between the pillows, are rich in diopside. In chemical composition these flows correspond to tholeiitic basalt although komatiites, with about 20 percent $\mathrm{Mgo}$, are also present; these consist mainly of tremolite and olivine. Pillow structures have also been recognized, and in some exposures the komatiitic rocks exhibit an intrusive character, cutting the amphibolitic pillow lavas (Kousa 1985).

Layers of silicate, oxide, and sulfide facies are found in the narrow iron formation. Silicate facies dominates and is composed mainly of quartzgarnet-grunerite rock, although layers rich in hornblende, diopside, fayalite, and chert also occur (Fig. 2). The oxide facies consists of magnetite and quartz with some grunerite and diopside. The sulfide facies contains pyrrhotite, pyrite, and lesser amounts of chalcopyrite.

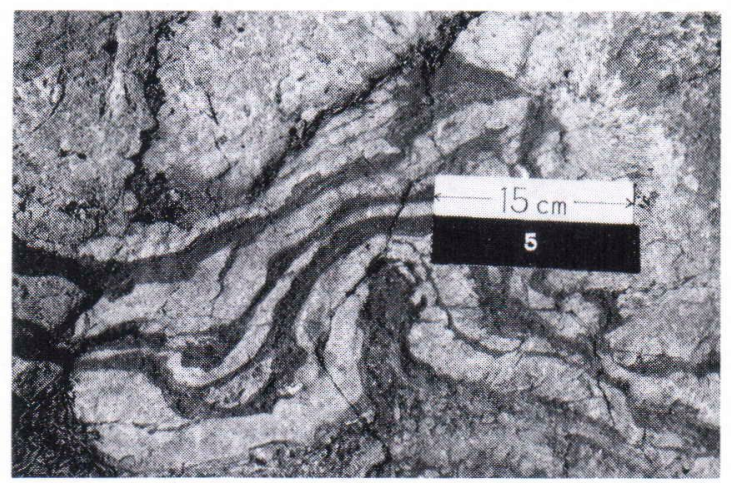

Fig. 2. Folded chert (light colored) and iron silicate layers in the iron formation. 


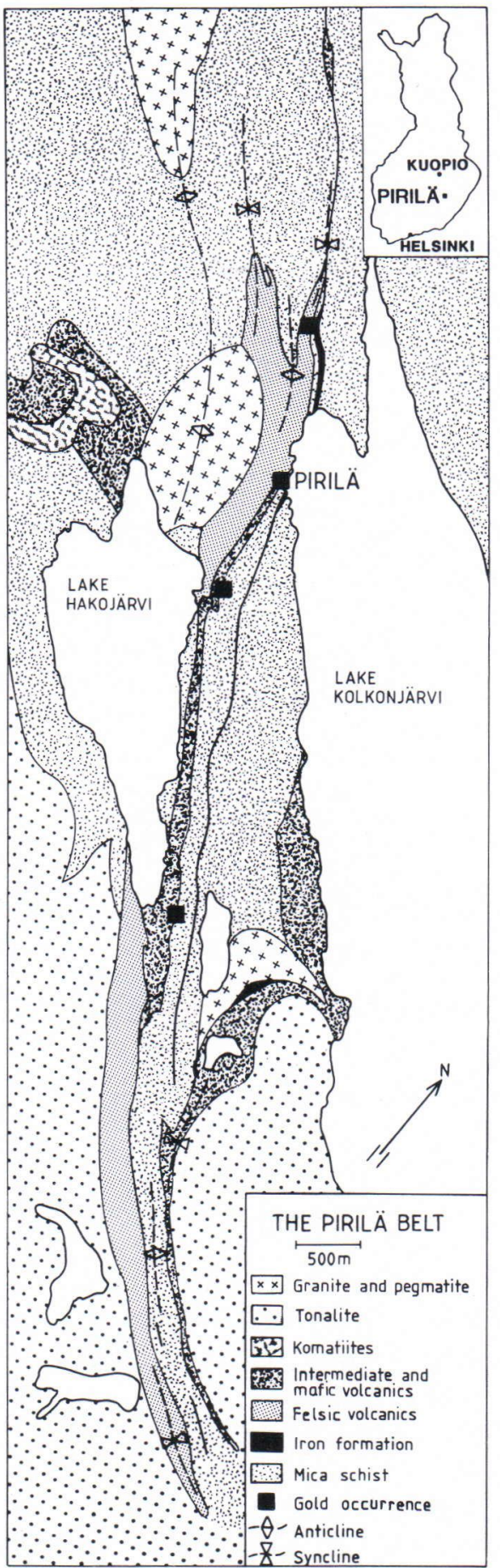

Fig. 3. Geologic map of the Pirilä belt. Partly after Korsman (1973).
The felsic and intermediate volcanics together with the iron formation form a narrow NNWSSE trending belt, called here the Pirilä belt, which can be followed for at least $30 \mathrm{~km}$. Figure 3 shows the southernmost part of the belt. Gold occurrences have been found in the contact zone between the volcanics and mica schists. In the southern part of the Pirilä belt, scheelite-bearing layers of garnet- and diopside-bearing calcsilicate rock are interbedded in the volcanic rocks.

\section{Stratigraphy}

No stratigraphic studies have been published on the area, but, the same rock associations are recognized in surrounding areas, where the stratigraphy has been studied. According to Hyvärinen (1969), the stratigraphy in the Virtasalmi area, about $30 \mathrm{~km}$ west of Pirilä, from oldest to youngest is as follows: mica schist (with black shale intercalations) overlain by quartzfeldspargneiss and diopsidegneiss, which in turn are overlain by limestone, amphibolite, and mica schist.

In the Haukivesi area, north of Pirilä, early metapelites are overlain by mafic volcanics, and these in turn by metaturbidites (Gaál and Rauhamäki 1971).

Simonen (1982) has suggested that in the Mikkeli area, about $40 \mathrm{~km}$ southwest of Pirilä, the quartz-feldspar gneisses and the diopside amphibolites are stratigraphically below the mica schist. On the basis of the studies made by the authors so far the following stratigraphy is suggested for the Pirilä area:

granite, pegmatite tonalite

komatiite

mafic volcanics

intermediate volcanics

felsic volcanics

iron formation

mica schist

basement unknown 
In many places iron formation is absent, and felsic agglomerate and lapilli tuff lie directly above the mica schist. At other sites intermediate volcanics occur above the mica schist. Outside the Pirilä area the intermediate volcanics are absent, and the oldest volcanic unit consists of mafic pillow lava. Tonalite intrudes the mafic volcanics and is therefore younger than the supracrustal rocks. The U-Pb age of the zircon in tonalite is $1888 \pm 15 \mathrm{Ma}$ (Korsman et al. 1984). The supracrustal rocks around the tonalite domes are foliated concordantly with the contacts. In contrast, later granites distinctly cut the tonalite.

\section{Metamorphism and structures}

The region has recently been the subject of several metamorphic studies (Korsman 1977; Korsman et al. 1984; Korsman and Kilpeläinen 1986).

According to Korsman et al. (1984), a thermal dome south of Pirilä caused characteristic metamorphic zoning. Towards the center of the dome the metamorphic grade increases up to that of granulite facies, and at the margin of the dome the pelites are metamorphosed into garnetcordierite-sillimanite gneisses. In many places anatexis has produced large volumes of pegmatite. Progressive metamorphism in the Rantasalmi-Sulkava area resembles the metamorphism of tectonically thickened crust.

Korsman (1977) and Korsman et al. (1984) recognized the following metamorphic zones: andalusite-muscovite, K-feldspar-sillimanite, Kfeldspar-cordierite, garnet-cordierite-biotite and garnet-cordierite-sillimanite. In figure 4 the isograds are shown according to Korsman et al. (1984). The Pirilä gold deposit is located in the K-feldspar-sillimanite zone.

The structures in the Pirilä area are complicated by several superimposed deformation phases. The area lies roughly within the Ladoga-Bothnian Bay Zone, which is characterized by various faults and lineaments. A fault several hundred kilometers long can be traced along Lake
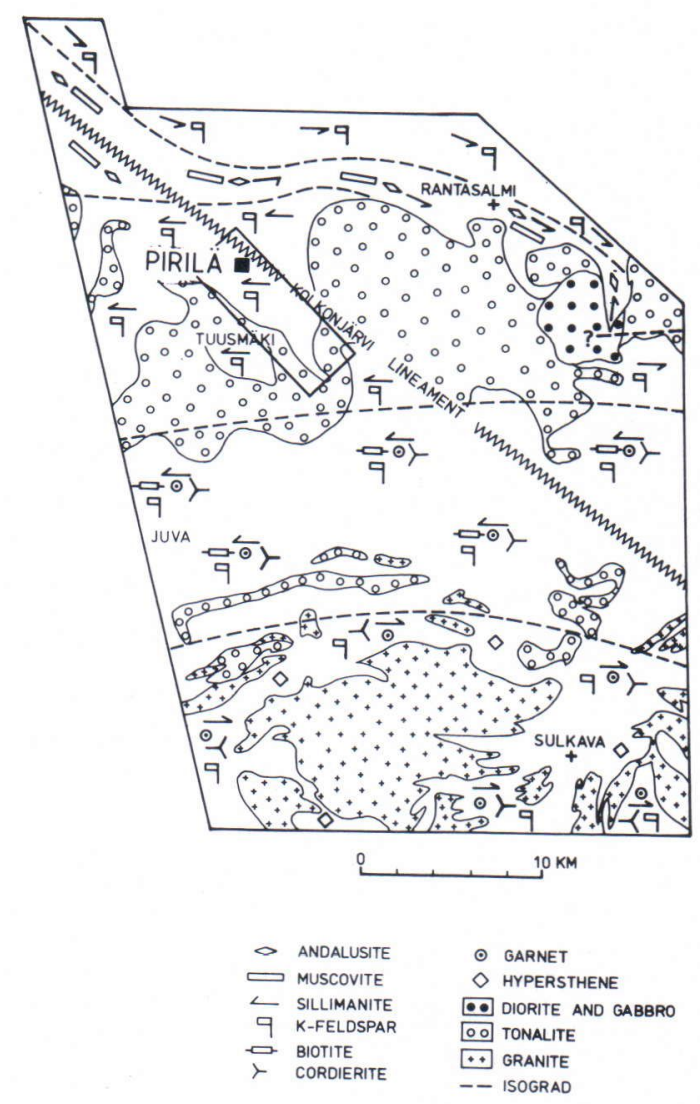

Fig. 4. Metamorphic map of the Rantasalmi-Sulkava area after Korsman et al. (1984, p. 9). Rectangle shows the location of the map in Fig. 3.

Kolkonjärvi close to the Pirilä deposit (Gaál 1972; Korsman et al. 1984). According to Gaál (1986), this fault, which is marked in Fig. 4, is part of a subduction zone dipping to east under the Archean crust.

Movements along the Kolkonjärvi fault zone were mostly transcurrent and dextral and probably considerably affected the structures at Pirilä. They may also have played an important role in the concentration of gold.

According to Gaál and Rauhamäki (1971), three deformation phases can be distinguished in the Haukivesi area, north of Pirilä. Recumbent folds formed in the first phase were followed by inclined to upright and dextral drag folds in the second phase. During the third deformation 
phase, the $\mathrm{F}_{2}$ folds were deformed into culminations and depressions.

Korsman and Kilpeläinen (1986) have established four successive deformation phases important in terms of progressive metamorphism in the Rantasalmi-Sulkava metapelites. $F_{1}$ folds are subisoclinal and $\mathrm{S}_{1}$ schistosity is generally very weak. $F_{2}$ folds are isoclinal with a wavelength of several hundreds of meters. The intensity of the $\mathrm{S}_{2}$ schistosity increases with the increase in metamorphic grade. $F_{3}$ folds are asymmetric and vary in size. Sillimanite, which is abundant in the Pirilä area, crystallized during the $\mathrm{F}_{2}$ phase and was deformed in the $\mathrm{F}_{3}$ phase. $\mathrm{S}_{4}$ schistosity is seen as crenulation and folding deforming the older structures.

The volcanics occur within $F_{2}$ synforms enveloped by mica schist (see Fig. 3). Larger granite and pegmatite intrusions are found in antiforms, and their lack of $\mathrm{S}_{2}$ schistosity suggests that they are post $F_{2}$ intrusions. $S_{2}$ schistosity is present in tonalite, indicating that the tonalite intruded before or during the $\mathrm{F}_{2}$ phase.

\section{The Pirilä gold deposit}

\section{Mode of occurrence}

Stratigraphically the gold deposit lies in the contact zone between the mica schist and the volcanics. The uppermost part of the mica schist, stratigraphically just below the deposit, is an iron-rich layer, as shown by the presence of garnet and hornblende.

The host lithologies of the deposit are a quartz rock, which occurs as lenses and veins, and the associated quartz-cummingtonite rock. Macroscopically, the quartz is bright, and glassy and differs from the dusty quartz of the younger pegmatites. The main minerals in the quartzcummingtonite rock are quartz, cummingtonite $(2 \mathrm{~V}+)$, and sometimes also biotite. Pseudomorphs of orthopyroxene have been found in one sample. Large $(\leq 2 \mathrm{~cm})$ garnet porphyroblasts occur here and there throughout the quartz rock.
Thus, the quartz-cummingtonite rock is mineralogically analogous to the silicate facies of the iron formation.

The exposed southern part of the deposit is located within a $\mathrm{F}_{3}$ hinge zone (Kilpeläinen 1986, pers. commun.), while the northern part is a vertical plate on the $\mathrm{F}_{2}$ axial plane (Figs. 5 and 6). The $F_{2}$ and $F_{3}$ fold axes plunge $35^{\circ}$ and $50^{\circ}$ to southeast, respectively.

Quartz lenses and veins are concordantly with the $S_{2}$ schistosity or $F_{3}$ folds, which vary in wavelength from a few centimeters to about 10 $\mathrm{m}$ (Fig. 5). $\mathrm{S}_{2}$ schistosity is visible in the quartzcummingtonite rock, indicating that it crystallized during or before the $\mathrm{F}_{2}$ phase.

Owing to the large number of bore holes it has been possible to study the shape and structure of the deposit in some detail, and the charged potential method has been applied succesfully in connecting the different ore intersections.

The fold structures visible in outcrop can also be recognized in cross sections (Fig. 7). The thickest quartz lens, which is also the richest in gold,

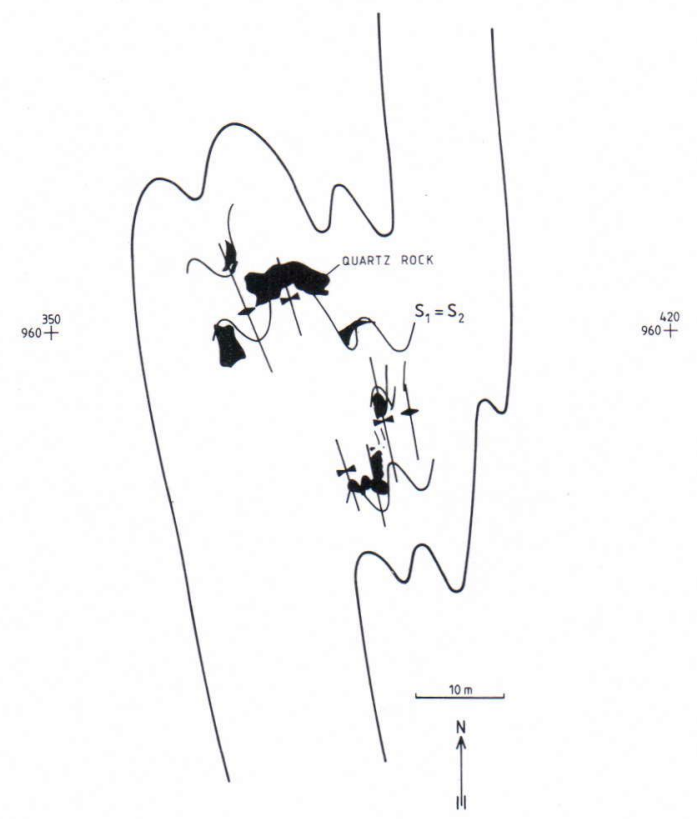

Fig. 5. Structural control of the mineralization. Quartz rock is marked in black. 


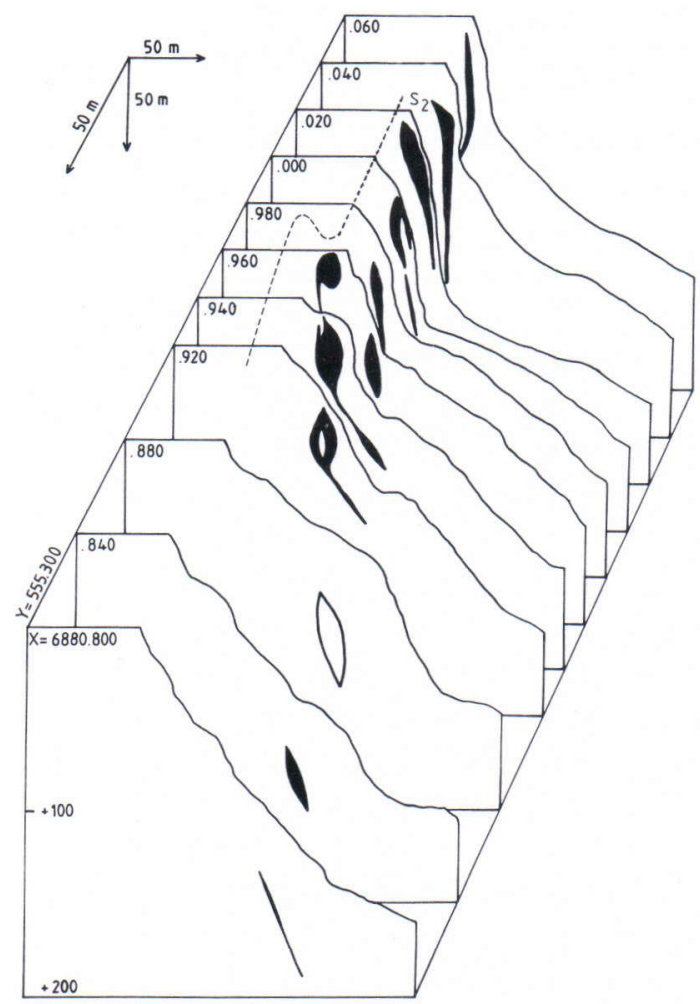

Fig. 6. Three dimensional model of the deposit. Black refers to the mineralized quartz rock ( $\mathrm{Au} \geq 1 \mathrm{ppm})$.

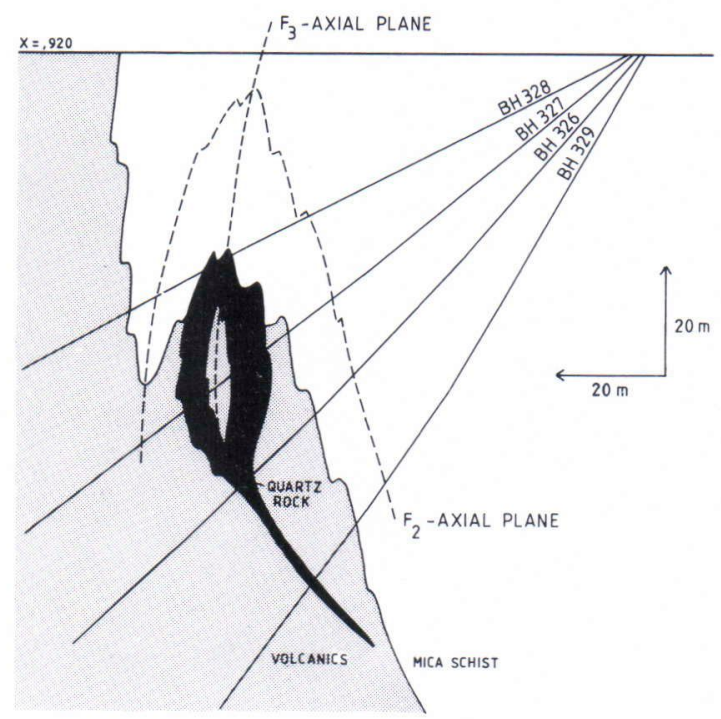

Fig. 7. Cross section of the deposit in the drilling profile $\mathrm{X}=.920$. is located in an $\mathrm{F}_{3}$ antiform, and parallels the plunge of the $\mathrm{F}_{3}$ fold axis. Down to a level of $200 \mathrm{~m}$, each drilling profile south of the exposure, shows the same antiformal structure, although the thickness of the lens varies.

\section{Ore mineralogy}

The ore minerals are encountered in both the quartz rock and the quartz-cummingtonite rock. In the quartz rock they occur as inhomogeneous disseminations or compact veins of varying thickness $(\leq 65 \mathrm{~cm})$, whereas the dissemination in the quartz-cummingtonite rock is more homogeneous and the grain size smaller. It is thus probable that the mineralization in the quartz rock represents a more mobilized type than that in the quartz-cummingtonite rock.

The most common ore minerals are arsenopyrite, löllingite, pyrrhotite, and pyrite, although locally galena, sphalerite, and chalcopyrite may also be abundant.

Gold occurs as electrum in arsenopyrite and löllingite and very often at the contact of arsenopyrite and löllingite grains (Fig. 8). In the analyzed electrum grains the silver content ranges from 10.6 to 60.0 percent. The core of the arsenosulphides is löllingite and the margin arsenopyrite. When gold-bearing, the arsenopyrite is very often fractured, with gold in the cracks. The grains usually occur as accumulations or rows, and the shape of individual grains is angular but irregular. Individual arsenopyritelöllingite grains often contain more gold than massive portions. The grain size is usually $<0.05$ $\mathrm{mm}$. The electrum grains in quartz and between the cummingtonite grains are much larger than those in the arsenopyrite-löllingite grains, the largest being $3 \mathrm{~mm}$ long.

Silver occurs mainly as small dyscrasite inclusions in galena (Fig. 9). Some secondary silver minerals have also been noted. According to microprobe analyses, electrum grades into dyscrasite with increasing antimony content (Fig. 10). When the silver content exceeds 60 percent, 
Fig. 8. Electrum grains in the contact between arsenopyrite (dark gray) and löllingite (gray). Nicols partly crossed.

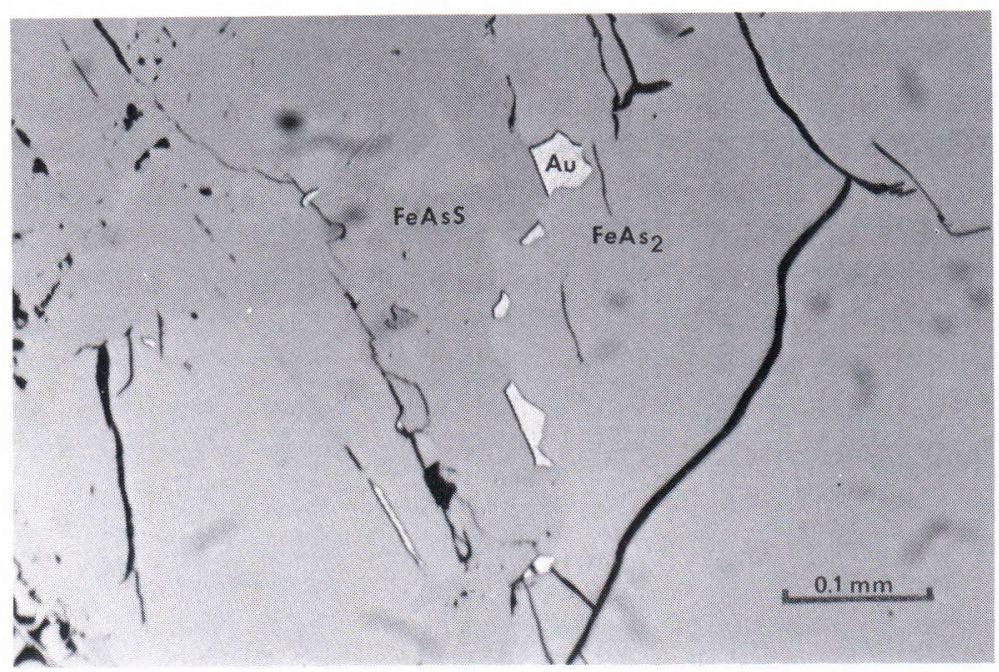

Fig. 9. Dyscrasite inclusions in galena. One nicol.

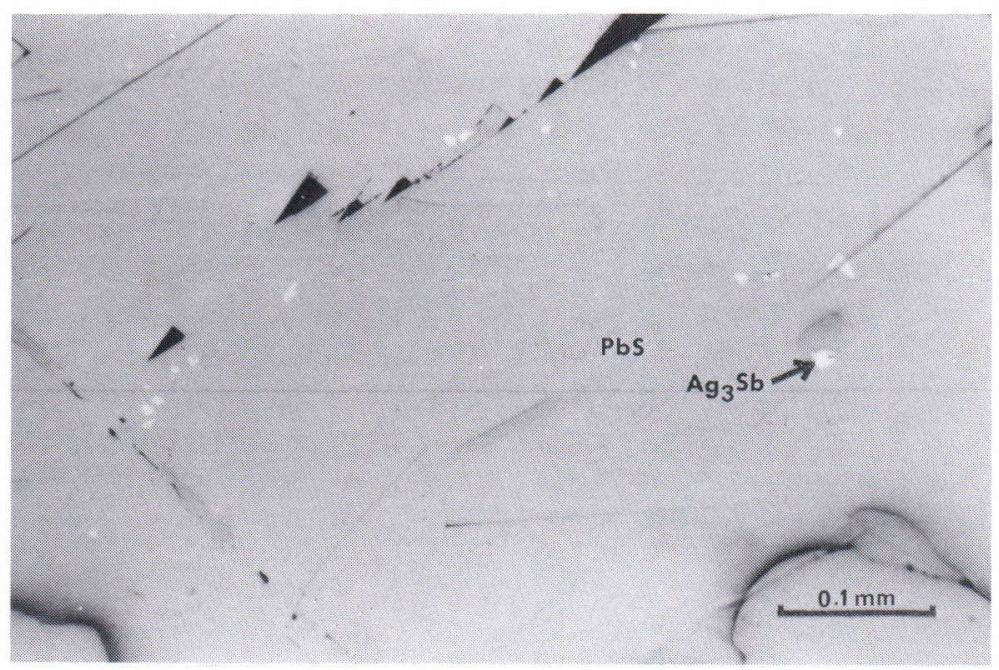

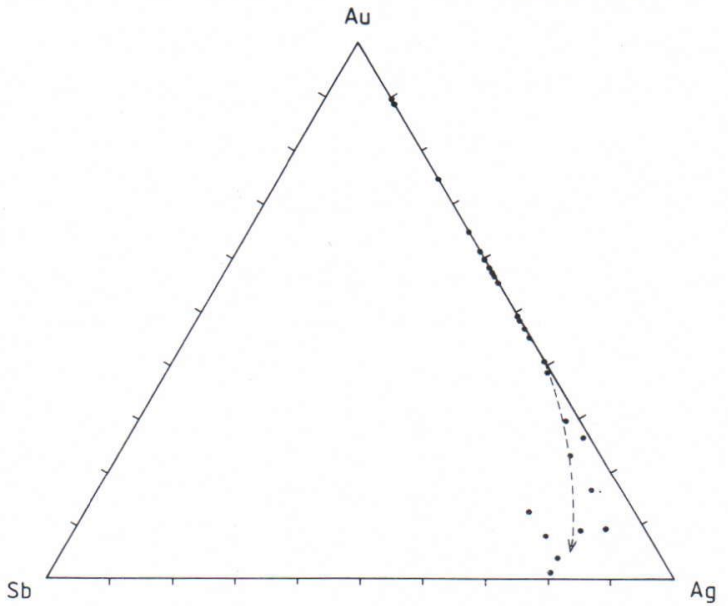

Fig. 10. Composition of electrum-dyscrasite. the antimony content starts to increase. In extreme cases, the composition approaches that of pure dyscrasite.

\section{Chemical composition}

Higher gold contents are restricted to the quartz rock and the quartz-cummingtonite rock. For example, in the iron formation east of the gold occurrence no contents exceeding $100 \mathrm{ppb}$ have been recorded.

Gold contents vary throughout the deposit from tens of grams per ton to several ppb in vir- 

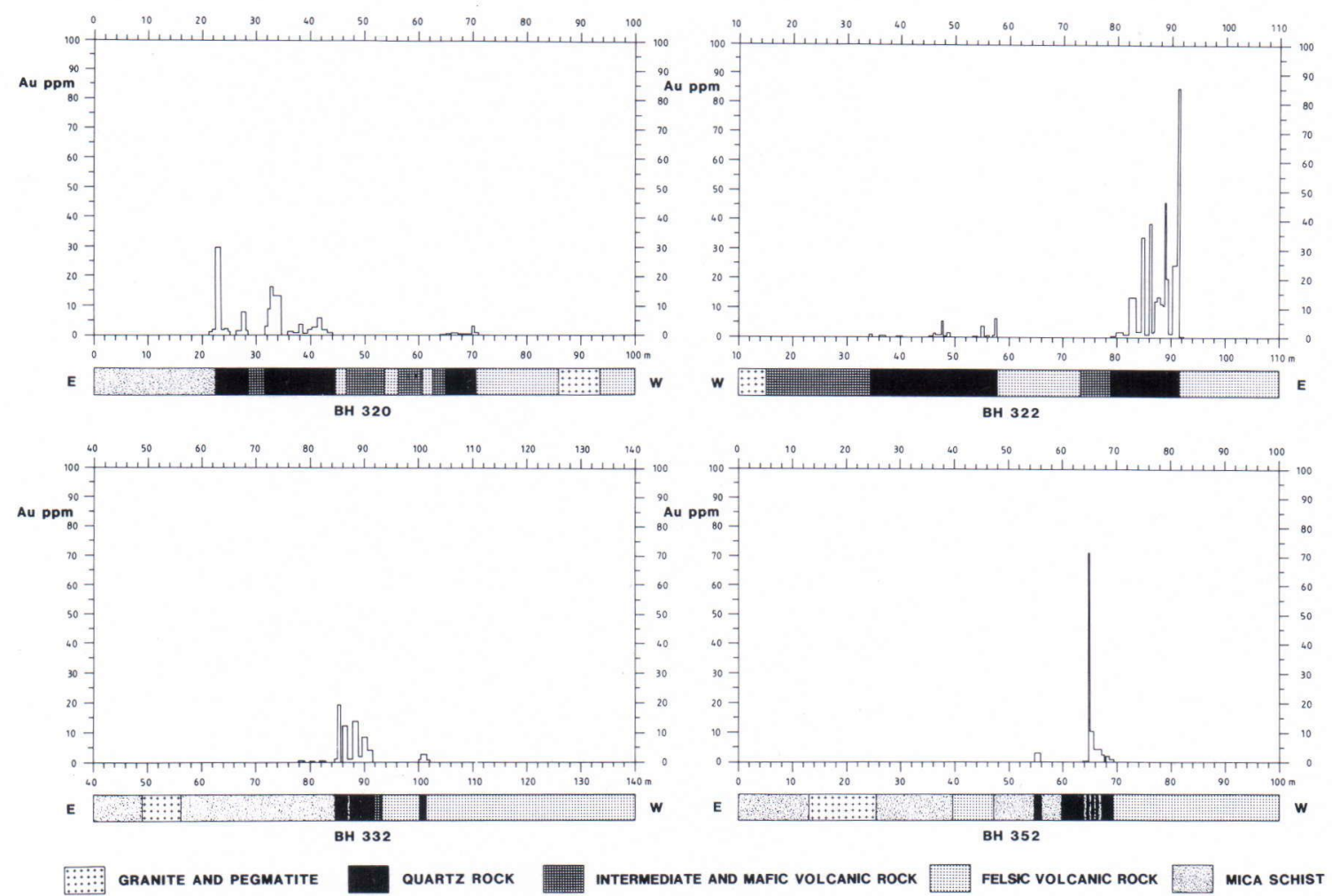

Fig. 11. Gold contents in some ore intersections.

tually adjacent samples. The highest contents analyzed from drill-core samples $(0.5 \mathrm{~m}$ in length) are of the order of hundreds of grams per ton; in such samples gold is macroscopically visible. The gold analyses presented in Fig. 11 give a good idea of the variation in gold content in the deposit. It is also evident from Fig. 11 that high gold contents favour the eastern portion of the deposit; this feature is very clear in drill hole $\mathbf{3 2 2}$.

Gold shows no clear correlation with any other metals analyzed from the deposit (Table 1). The content of gold does not correlate with that of arsenic, although gold occurs mainly in arsenic minerals. On the other hand, the fact that gold

Table 1. Correlation matrix of the elements analyzed systematically from the Pirilä deposit. Analyses refer to the drill core samples that contain between $1 \mathrm{ppm}$ and $100 \mathrm{ppm}$ gold $(\mathrm{n}=211)$.

\begin{tabular}{lllllllll}
\hline & $\mathrm{Au}$ & $\mathrm{Ag}$ & $\mathrm{Cu}$ & $\mathrm{Zn}$ & $\mathrm{Pb}$ & $\mathrm{Ni}$ & $\mathrm{Co}$ & $\mathrm{As}$ \\
\hline $\mathrm{Au}$ & 1.00 & & & & & & & \\
$\mathrm{Ag}$ & 0.36 & 1.00 & & & & & & \\
$\mathrm{Cu}$ & 0.21 & 0.27 & 1.00 & & & & & \\
$\mathrm{Zn}$ & 0.40 & 0.35 & -0.04 & 1.00 & & & \\
$\mathrm{~Pb}$ & 0.21 & 0.86 & 0.02 & 0.35 & 1.00 & & & \\
$\mathrm{Ni}$ & 0.24 & 0.11 & 0.14 & 0.02 & 0.13 & 1.00 & & \\
$\mathrm{Co}$ & 0.15 & 0.08 & 0.27 & 0.00 & 0.10 & 0.72 & 0.00 & 1.00 \\
$\mathrm{As}$ & 0.31 & 0.07 & 0.24 & -0.02 & 0.07 & 0.65 & 0.72 & 1.00 \\
$\mathrm{~S}$ & 0.41 & 0.49 & 0.35 & 0.32 & 0.46 & 0.43 & 0.54 & 0.68 \\
\hline
\end{tabular}


Fig. 12. Gold versus arsenic and silver versus lead diagrams, with a regression line in the silver-lead diagram. The samples are the same as in the correlation matrix.
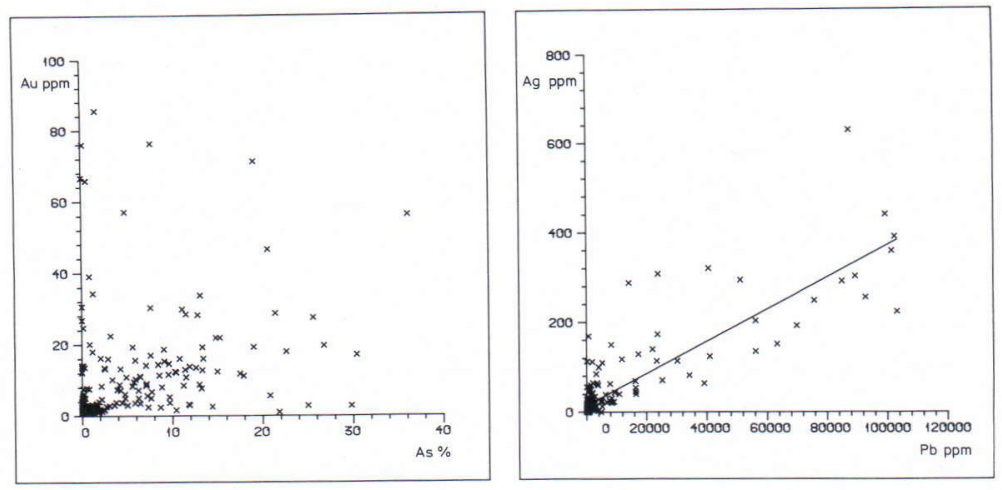

also occurs with silicates naturally disturbs the correlations. The strong positive correlation between lead and silver is ascribed to the dyscrasite inclusions, which occur only in galena (Fig. 12).
Platinum and palladium were analyzed from one drill core (14 samples). In one sample the contents exceeded the detection limit $(0.02 \mathrm{ppm})$, being $0.1 \mathrm{ppm} P t$ and $0.1 \mathrm{ppm} \mathrm{Pd}$. The sample also had the highest gold value analyzed from the

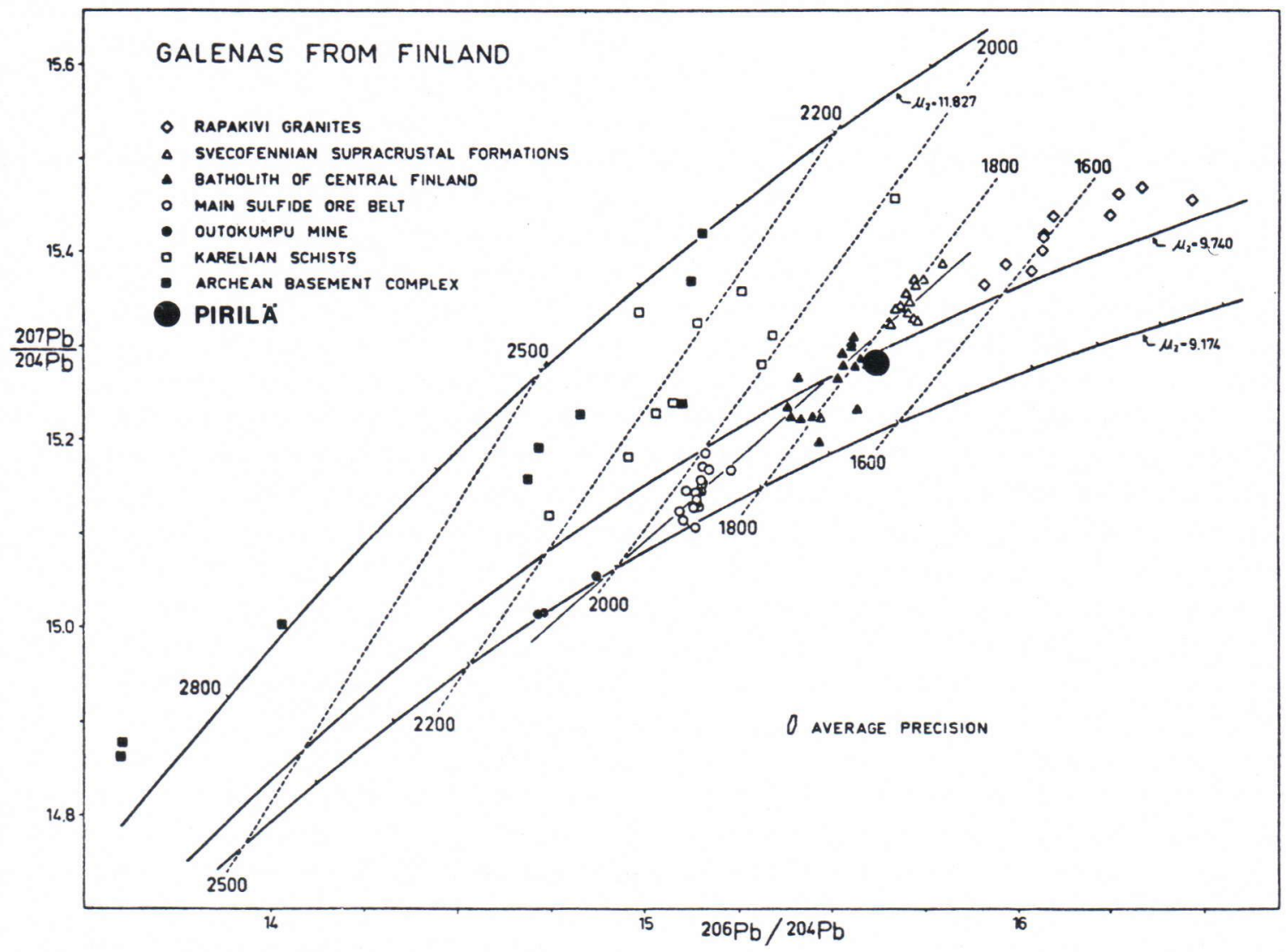

Fig. 13. The lead isotopic composition of galena from Pirilä compared with those from other areas in Finland (Vaasjoki 1981, Fig. 2). 
deposit, $786 \mathrm{ppm}$. Antimony and bismuth were analyzed from 155 surface samples, the highest values being $190 \mathrm{ppm} \mathrm{Sb}$ and $800 \mathrm{ppm} \mathrm{Bi}$. The $\mathrm{Sb}$ and $\mathrm{Bi}$ contents were usually below the detection limit (100 ppm for $\mathrm{Sb}$ and $10 \mathrm{ppm}$ for $\mathrm{Bi}$ ) and therefore the antimony and bismuth contents could not be compared with those of the other elements.

The average $\mathrm{Au} / \mathrm{Ag}$ ratio of the deposit is 0.27 , ranging in the drilling profiles from 0.06 to 1.51 . The average $10000 \times \mathrm{Au} / \mathrm{As}$ ratio is $2.96, \mathrm{Cu} / \mathrm{Au}$ 213, and $\mathrm{Zn} / \mathrm{Au} 124$. The ratios were calculated from the average grades of the ore reserve estimations. No vertical or lateral changes were observed in the metal ratios of the deposit.

The lead isotope composition of one galena sample, determined at the geochronological laboratory of the Geological Survey of Finland, is similar to that of the galenas in the Central Finland batholith area (Vaasjoki 1981) (Fig. 13).

\section{Discussion}

According to the classification of gold deposits by Boyle (1979), the Pirilä deposit belongs to the category »disseminated gold-silver deposits in volcanoclastic and sedimentary beds: deposits in tuffaceous rocks and iron formations». Gold deposits of varying age, but very similar to Pirilä, occur in North America. In the Homestake formation, South Dakota, which includes mineralized pipes, pods, veins, saddles, and lenses, Fe$\mathrm{Mg}$ carbonate sediments have been converted into cummingtonite schist (Slaughter 1968). In the vicinity of Contwoyto Lake, Northwest Territories, Canada, layers and lenses of sulfide bearing cummingtonite gneisses are interbedded with Archean graywacke and argillite. The richest gold-bearing parts occur on the crests of folds and the principal minerals in these parts are garnet, cummingtonite, quartz, pyrite, pyrrhotite, arsenopyrite, löllingite, chalcopyrite, and native gold (McConnel 1964).

Features similar to the Pirilä area also occur in Superior Province. According to Hodgson and MacGeehan (1982), the gold deposits there often occur in the contact between sediments and volcanics. However, the stratigraphy of the Pirilä Proterozoic study area is inverted relative to the Archean Superior Province, where the sediments usually overlie the volcanics.

The genesis of gold deposits associated with iron formation has been widely discussed, with both syngenetic and epigenetic models having been proposed.

Syngenetic models have been advocated by Ridler (1970) and Hutchinson et al. (1971), and according to Sawkins and Rye (1974), the gold deposits of the Homestake formation are primarily syngenetic, associated with carbonate facies iron formations. Gold and sulfides were upgraded during metamorphism. Fripp (1976) suggested that the stratabound gold deposits associated with Archean iron formations in Zimbabwe are syngenetic. Gold was apparently precipitated from active fumaroles in the mixed sulfidecarbonate facies iron formation, which is now represented by alternate layers rich in chert, arsenopyrite, pyrrhotite, and ankerite.

According to Phillips et al. (1984), many deposits earlier considered syngenetic show strong evidence for an epigenetic origin, for example, the boundaries between sulfides and oxide facies banded iron formation are sharp, and iron oxides or carbonates are replaced by sulfides. According to the epigenetic model, gold is precipitated from metamorphic auriferous $\mathrm{H}_{2} \mathrm{O}$ $\mathrm{CO}_{2}-\mathrm{H}_{2} \mathrm{~S}$ solutions owing to interaction with $\mathrm{Fe}$ rich host rocks. The solutions are formed under high amphibolite facies conditions as a result of dehydration and decarbonization. Precipitation takes place near the border of amphibolite facies and greenschist facies (Groves et al. 1985). Typical of epigenetic deposits of this type are low $\mathrm{Cu} / \mathrm{Au}, \mathrm{Zn} / \mathrm{Au}$, and $\mathrm{Ag} / \mathrm{Au}$ ratios compared with syngenetic exhalative deposits (Phillips et al. 1984).

Some features speak for a syngenetic origin for the Pirilä deposit. Firstly, mineralization is 
stratabound in nature. In the metamorphic model (Phillips et al. 1984, Groves et al. 1985), the ore solutions are precipitated along the amphibolitegreenschist facies boundary, whereas in the Pirilä area the gold-bearing zone cuts the general trend of metamorphic isograds (Fig. 4). Certain layers in the deposit contain several percent copper, zinc, or lead; this is not typical of epigenetic deposits, which tend to have very low base me$\mathrm{tal} /$ gold ratios. Also the $\mathrm{Ag} / \mathrm{Au}$ ratio is high for an epigenetic deposit. The mineralogy in the iron formation and in the host rocks of the deposit is similar. It is possible that the quartz lenses in the deposit correspond to chert layers in the iron formation. The primary source for the gold in the deposit was probably magmatic, now represented by the volcanics of the Pirilä belt and by the tonalite bodies south and southeast of Pirilä (Fig. 4).

More detailed studies on trace metals, isotopes, and fluid inclusions in the Pirilä deposit are in progress and will probably clarify the origin of the mineralization.

Acknowledgements. We are grateful to Prof. Gabor Gaál and Prof. Heikki Papunen for their comments on the manuscript and to Dr. Kari Kojonen, who assisted us in the ore microscopic studies. Discussions with Olavi Kontoniemi were very useful. We thank also Mrs. Raija Väänänen, who drew the figures and Mrs. Gillian Häkli, who corrected the English of the manuscript.

\section{References}

Boyle, R. W., 1979. The geochemistry of gold and its deposits Can. Geol. Survey, Bull. 280, 584 p.

Fripp, R. E. P., 1976. Stratabound gold deposits in Archean banded iron-formation, Rhodesia. Econ. Geol. 71, $58-75$.

Gaál, G., 1972. Tectonic control of some Ni-Cu deposits in Finland. 24th Int. Geol. Congr., Sect. 4, 215-224.

-, 1986. 2200 million years of crustal evolution: The Baltic shield. Bull. Geol. Soc. Finland 58, 149-168.

— \& Rauhamäki, E., 1971. Petrological and structural analysis of the Haukivesi area between Varkaus and Savonlinna, Finland. Bull. Geol. Soc. Finland 43, 265-337.

Groves, D. I.; Phillips, G. N.; Ho, S. E. \& Houston, S. M., 1985. The nature, genesis and regional controls of gold mineralization in Archaean greenstone belts of the Western Australian Shield: a brief review. Trans. Geol. Soc. S. Africa 88, 135-148.

Hodgson, C. J.\& MacGeehan, P. J., 1982. A review of the geological characteristics of »gold-only» deposits in the Superior Province of the Canadian Shield. Can. Inst. Min. Metall., Spec. Vol. 24, 101-112.

Hutchinson, R. W.; Ridler, R. H. \& Suffel, G. G., 1971. Metallogenic relationships in the Abitibi belt, Canada: A model for Archean metallogeny. Can. Inst. Min. Metall. Trans. 74, 106-115.

Hyvärinen, L., 1969. On the geology of the copper ore field in the Virtasalmi area, eastern Finland. Bull. Comm. Geol. Finlande 240, 82 p.

Kahma, A., 1973. The main metallogenic features of Finland. Geol. Surv. Finland, Bull. 265, 29 p.
Korsman, K., 1973. Pre-Quaternary rocks, Sheet 3233, Rantasalmi. Geological Map of Finland, $1: 100000$.

_, 1977. Progressive metamorphism of the metapelites in the Rantasalmi-Sulkava area, southeastern Finland. Geol. Surv. Finland, Bull. 290, 82.p.

-; Hölttä, P.; Hautala, T.\& Wasenius, P., 1984. Metamorphism as an indicator of evolution and structure of the crust in eastern Finland. Geol. Surv. Finland, Bull. 328 $40 \mathrm{p}$.

— \& Kilpeläinen, T., 1986. Relationship between zonal metamorphism and deformation in the RantasalmiSulkava area, southeastern Finland. Geol. Surv. Finland, Bull. 339, 33-42.

Kousa, J., 1985. Rantasalmen tholeiittisista ja komatiittisista vulkaniiteista. Summary: The tholeiitic and komatiitic metavolcanics in Rantasalmi, Southeastern Finland. Geologi 37 (2), 17-22.

McConnel, G. W., 1964. Notes on similarities between some Canadian gold deposits and the Homestake deposits of South Dakota. Econ. Geol. 59, 719-720.

Phillips, G. N.; Groves, D. I. \& Martyn, J. E., 1984. An epigenetic origin for Archean banded iron-formationhosted gold deposits. Econ. Geol. 79, 162-171.

Ridler, R. H., 1970. Relationship of mineralization to volcanic stratigraphy in the Kirkland-Larder Lakes area, Ontario. Geol. Assoc. Can., Ann. Meet. Proc. 21, 33-42.

Sawkins, F. J. \& Rye, D. M., 1974. Relationship of Homestake-type gold deposits to iron-rich Precambrian sedimentary rocks. Inst. Min. Metall., Trans. B 83, B56-B59.

Simonen, A., 1980. The Precambrian in Finland. Geol. Surv. Finland, Bull. 304, 58 p. 
—, 1982. Mäntyharjun ja Mikkelin kartta-alueiden kallioperä. Summary: Pre Quaternary rocks of the Mäntyharju and Mikkeli map-sheet areas. Explanation to maps of rocks, Suomen geologinen kartta 1 : 100000 sheets 3123 Mäntyharju ja 3142 Mikkeli, $36 \mathrm{p}$.

Slaughter, A. L., 1968. The Homestake mine. In Ridge, J. Received January 15, 1988

D. (ed.) Ore deposits of the United States, 1933-1967, Revised and accepted March 7, 1988
Vol. 2, pp. 1436-1459.

Vaasjoki, M., 1981. The lead isotopic composition of some Finnish galenas. Geol. Surv. Finland, Bull. 316, 25 p. 